\title{
Building Earth and Low Carbon Initiatives For Sustainable Housing in Nigeria
}

\author{
Olotuah M. Ayobami, Olotuah A. Albert and Olotuah O. Abiodun
}

\begin{abstract}
Housing need in Nigeria is continuously on the increase both, in the rural and urban areas. Studies have shown overwhelming evidences of the appalling situation of housing in Nigeria, as it is the case in most Less Developed Countries. Housing development however could be greatly facilitated by recourse to the use of improved building materials of earthen origin. The materials offer low carbon solutions in housing thus contributing to the development of sustainable housing. Sustainable housing is environmentally-conscious housing that seeks to minimize the negative environmental impact of buildings by enhancing energy efficiency, moderation in the use of materials, and development of space. This is important in enhancing health, welfare, and productivity of occupants of buildings, and it is cost effective. This paper appraises the use of building earth and supplementary cementitious materials as low carbon initiatives in sustainable housing in Nigeria. It asserts that the development of sustainable housing could be readily achieved in Nigeria with the adoption and use of building materials of earthen origin and some supplementary cementitious materials.
\end{abstract}

Keywords: building, development, housing, resources, sustainable.

\section{INTRODUCTION}

The development of housing is of paramount importance in the socio-economic growth of a nation and in the lives of individuals. Housing is recognized as an essential requirement for human existence [1]. It transcends shelter, the functions of which are protection from the elements of weather, safety from human vices and animal predators. It encompasses the services and amenities provided in the dwelling unit and the environment within which this is situated. It is therefore the total environment where man lives and grows, that meets his biological, physical, and material needs [2]. Housing facilitates the development of human potential and adequacy in it enhances the health, well-being, and productivity of people [3].

Housing development stimulates the economy of a nation and it is a basis for guided urban development. The multiplier effect on the economy is enormous since residential construction usually generates employment and involves huge financial investment. The heterogeneous nature of the housing

Olotuah M. Ayobami, Federal University of Technology Akure, Nigeria Olotuah A. Albert, Ahmadu Bello University Zaria, Nigeria

Olotuah O. Abiodun, Federal University of Technology Akure, Nigeria market offers the opportunity for a wide range of goods and services that have economic benefits for tradesmen, manufacturers, and suppliers, aside from housing professionals.

The housing problems in urban centres in Nigeria encompass qualitative and quantitative deficiencies in the existing stock. The problems result mainly from the rapid urbanisation occurring in the country. The rate of formation of urban centres has climbed steadily over the years. In the 1930s only $7 \%$ of Nigerians lived in urban centres. In 1950 the percentage had risen to $10 \%$, and by 1970,1980 , and 1990 , the percentage of Nigerians that lived in cities were 20\%, 27\%, and $35 \%$ respectively $[4,5]$. According to the 2006 Census result, the population of Nigeria was about 140 million, showing an overall population growth rate of about $3.2 \%$ over the 1991 Census [6]. The urban growth rate is usually more than the rural growth rate with the capital city Abuja growing at the rate of $9.3 \%$ [7-9]

Studies have shown an overwhelming evidence of the deplorable and pathetic housing conditions in which the vast majority of urban dwellers in Nigeria live [10-15]. These show the preponderance of sub-standard and structurally unsound houses found in urban centres in Nigeria. The buildings are often constructed with poor quality materials with walls of poor sandcrete blocks, and concrete containing excessive quantities of dust and clayey matter. In most cases the environment in which the buildings are located is squalid, and this generally leads to slum conditions [16].

Earth is reputed to be man's oldest building material. A third of the population of the world still resides in houses built with earth materials [17]. The vast majority of these are in subSaharan Africa and Asia. This paper examines the use of earth materials as building materials, and which are readily available in Nigeria, in sufficient quantities, to support the development of sustainable housing. Sustainable housing ensures satisfaction, well-being, and productivity of users, and is environmentally-friendly. This paper examines low carbon initiatives in housing development in Nigeria based on the use of stabilized soil blocks, solid interlocking blocks, and supplementary cementitious materials. Energy-efficiency in buildings can be achieved through the adoption and use of low carbon initiatives in housing construction. Stabilized soil blocks and solid interlocking blocks have been shown to give low carbon solutions because of the rational use of natural resources, energy efficiency, elimination or reduction of 
generated waste, low toxicity, and water conservation [18]. Stabilized soil blocks, solid interlocking blocks, and supplementary cementitious materials are readily available in Nigeria and can be useful for sustainable housing development. Their use is for the purpose of reducing embodied energy in construction of houses and the reduction of operational energy in housing use.

\section{HoUSING AND SUSTAINABILITY}

Sustainable housing is environmentally conscious housing in which the negative environmental impact of houses is minimized by enhancing efficiency and moderation in the use of materials, energy, and development of space. The adoption of low carbon materials and construction techniques is a pragmatic approach to sustainable housing. This is important in enhancing health, welfare, and productivity of occupants of houses.

Housing is one of the four most important needs of mankind; the others being food, clothing, and medical care. The place of housing in human life is eminent necessitating its adequate provision in quantitative and qualitative terms. Housing, as a process, is the all-encompassing phenomenon of the creation of the living environment for human. It caters for human biological (clean air, water), psychological (satisfaction, contentment, prestige, privacy, choice, freedom, security) and social (interaction with others, human development and cultural activities) needs and is beneficial for human development.

Housing is paramount to quality of life and consumes large amounts of resources in its construction, maintenance, and use, and it thus contributes significantly to sustainability $[19,20]$. The building industry consumes $40 \%$ of the materials entering the global economy, and is responsible for almost half of the global greenhouse gases [21].

The use of low carbon earth materials is indigenous in Nigeria. Building earth is the traditional material for construction and is available vastly in the country. Extensive research has been carried out in the country, notably by the Nigerian Building and Road Research Institute (NBRRI), and has resulted in the use of stabilized blocks and solid interlocking blocks for walling, offering low carbon solutions [22]. Model experiments have been carried out in Nigeria with the use of these materials in mass housing projects.

Achieving sustainability in housing requires seeking solutions relating to energy saving, emissions control, production and application of materials, and the use of renewable resources since carbon dioxide $\left(\mathrm{CO}_{2}\right)$ is emitted to the atmosphere in great quantity through the whole life-cycle of a building. Carbon dioxide $\left(\mathrm{CO}_{2}\right)$ is emitted into the atmosphere during the production of building materials, the construction, renovation, rehabilitation, and demolition of a building [23].

Energy use in buildings comprise both the direct (construction, operation, maintenance, and deconstruction) and indirect (embodied energy of materials) energy. Embodied and operational carbon emissions could be reduced by the careful choice of materials and construction techniques [24]. Embodied energy is the energy used in the production and distribution of a product or material. It is the latent energy of a building associated with the materials of construction, construction process, and maintenance [25]. Embodied energy is important to energy efficiency and thus sustainability. It is an indicator of greenhouse gas emission or carbon footprint and can be used to assess environmental impacts, and hence a pointer to environmental sustainability [26, 27]

\section{BUILDING EARTH}

Nigeria is richly endowed in raw materials for the production of building components and materials [28-30]. The raw materials include clay (building earth), silicon, iron ore, limestone, timber, and gypsum. Earth is one of the oldest building materials known to man. It has been used in various forms in housing construction depending on the material type and the technology available. Clay is the building earth that is commonly employed in housing construction. This is an earth material of a size of about $0.002 \mathrm{~mm}$ in diameter usually brownish or reddish in colour. It is found in an admixture of other earth materials such as sand and silt. The sizes of these other materials are close to that of clay and are thus often difficult to separate from clay. The earth material used for construction is often a mixture of clay and sand in varying proportions and is referred to as mud. This is a versatile material which derives its plasticity from the clay component and its strength from the sand component. Silt vitiates the quality of building earth and a mixture of clay and silt is often so weak that it requires inner reinforcement.

There are large deposits of clay in Nigeria. Clay is found in all parts of the country. It is perhaps the most widespread mineral known in many parts of the country [31]. There are various types of clay minerals found in the deposits across the nation. These include kaolinite (white clay), montmorillonite, halloysite, attapulgite and illite clay. Kaolin is the most abundant mineral present in most clay deposits in Nigeria. The elements present in the kaolinite clays include silica, alumina, iron, calcium, magnesium, sodium, potassium, and phosphorous. The clay deposits differ in characteristics and properties (physical and chemical) from one part of the country to the other. This is due essentially to their varying constituent minerals. In the southwestern part of Nigeria, the most common is the argillaceous clay, which is grainy and greasy and is often mixed with sandy laterite soil. In Northern Nigeria, kaolinitic and montmorillonite clay deposits abound in large quantities. These are found in ferruginous tropical soils, ferrisols, hydromorphic, and alluvial soils [32].

Good quality building earth needs to be plastic, coherent and cementatous. While sand gives earth strength, clay is the binding material providing plasticity and cohesion of the mixture. Silt, on the other hand causes poor drainage and actually impedes proper functioning of building earth. Silt is therefore undesirable in building earth required for construction. It is however difficult to find a silt-less soil since its particle size lies between that of sand and clay. 
The obvious weaknesses of traditionally made sun-dried blocks are their low compressive strength and low durability if exposed to rain. The compressive strength of the blocks is improved upon by controlling the moulding water content and increasing the compacting pressure during production. The block-making machine produced by the Nigerian Building and Road Research Institute (NBRRI) which is hand-operated, operates with a compaction effort not less than $3 \mathrm{~N} / \mathrm{mm}^{2}$. Clay is mixed with water a little above the optimum level and the blocks are subjected to accelerated drying without shrinkage occurring during drying, thus giving them desirable compressive strength. In order to achieve desirable compressive strength and durability a number of techniques are employed. Below are examples of improved products obtained.

\section{Fired Clay Bricks}

The bricks are made from clay and other minerals, processed into a workable consistency and formed to standard sizes. These are then fired in a kiln to make them strong, durable, and attractive. Fired clay bricks can be made locally with the use of machine (the NBRRI has designed one) and fired in a simple clamp kiln. The fuels commonly used are wood and grass straws. The NBRRI has developed the down drought kiln using coal and diesel as fuels with high productivity.

\section{Earth Stabilized Blocks}

Earth stabilization is done to improve the properties of the blocks. This is achieved through addition of materials such as cement, bitumen, and lime in appropriate proportions. Cement is the most common stabilizing agent, the addition of which enhances cohesive nature of clay and increases the tensile strength of the blocks. Research findings by NBRRI have shown that $4 \%$ cement addition is sufficient to achieve excellent stabilization using the block-moulding machine designed by the institute with a minimum of $3 \mathrm{~N} / \mathrm{mm}^{2}$ compaction effort. Loam and silty-loam clay are suitable for stabilization with cement. Earth stabilization with $4 \%$ cement content gives an average compressive strength of $1.6 \mathrm{~N} / \mathrm{mm}^{2}$ [33].

Lime is also used for stabilization. It strengthens earth greatly when it reacts with the clay content of earth. Stabilization with lime is better with earth of high clay content while cement is preferred for earth with high sand content.

Stabilization with bitumen increases the tensile strength, pressure resistance, and water proofing properties of earthen walls. It also improves its thermal qualities of low heat conductivity and confers extreme internal dryness in the blocks, thus enhancing its durability even to the level of fired bricks.

Earth architecture has been improved upon considerably in Nigeria. Although clay is found in large quantities all over the country and is cheap, the quality of the walls built has to be put into consideration. In this regard, certain important parameters come into play in the use of clay as a building material and in particular as a viable alternative to conventional building materials. These include strength, size, and thermal conductivity [34].
Clays found in most deposits in the country are moderately plastic. In samples from clay deposits in Ado-Ekiti and Ikere-Ekiti, southwestern Nigeria, the plastic limit ranges from 21.58 to $22.48 \%$ (with the mean of 22.18), and the plasticity index from 20.45 to $24.7 \%$ (with the mean of 21.88) [35]. Quartz content is found to range from 1.7 to $35 \%$. Soil samples of clay deposits in Zaria, Northern Nigeria, have a mean plastic limit of 24\%, and plasticity index of 20\% [36]. The Nigerian Building and Road Research Institute (NBRRI) has conducted extensive research on the improvement of the quality of clay used for building [37-39]. These researches have shown that controlling the moulding water content and increasing the compacting pressure can improve properties of sun-dried bricks. The appearance of the bricks can also be improved with the use of rigid timber moulds for their production. Walls made with sun-dried bricks need to be protected from contact by heavy rain, through the provision of extended roof overhang or veranda running round the building.

\section{SuPPlEMENTARY CEMENTITIOUS MATERIALS}

An increase in the proportion of supplementary cementitious materials in cement is environmentally beneficial. The replacement of Portland cement with fly ash reduces the carbon footprint of concrete, as the production of one ton of Portland cement produces approximately one ton of $\mathrm{CO}_{2}$ compared to zero $\mathrm{CO}_{2}$ produced using fly ash. The use of fly ash reduces embodied energy and makes for sustainable development by eliminating the environmental hazard that the ash would otherwise have caused. Reduction of cement is economical and sustainable, and ensures reduction of embodied energy involved in its production and reduction of the associated carbon [40]. Ashes of some agricultural or other biogenic wastes such as rice husk, coconut husk, and peanut shell when mixed with appropriate amounts of Portland cement can be used as low-cost, less permeable, and environmentally more friendly binders for concrete production, than using Ordinary Portland cement alone [41].

\section{CONCLUSION}

The use of building earth and low carbon initiatives in housing development in Nigeria is the focus of this paper. Nigeria has a rich heritage in the extensive use of building earth and through research efforts low carbon solutions have been found in its use. Sustainable housing development could be facilitated with the development and use of building materials of earthen origin and some supplementary cementitious materials.

\section{REFERENCES}

[1] M. D. Yakubu Low-cost housing and housing for low-income groups, In the Proceedings of the $3^{\text {rd }}$ International Conference on Housing, August 17 - 24, 1980, Durbar Hotel, Kaduna. Nigeria, pp. 218 - 223, 1980

[2] A. O. Olotuah The house: accessibility and development - a critical evaluation of the Nigerian situation, In Bayo Amole (Ed.) The House in Nigeria, Proceedings of the National Symposium, Obafemi Awolowo University Ile - Ife, Nigeria, 23 - 24 July, pp. 312 - 317, 1997 
[3] P. M. Wilner The Housing Environment and Family Life. John Hopkins University Press, Baltimore, 1962

[4] A. L. Mabogunje Urbanisation in Nigeria, University of London, Press, London, 1968

[5] L. Okupe Private sector initiative in housing development in nigeria how feasible?, Housing Today, 1 (6), pp. 21 - 26, 2002

[6] V. O. Adegbehingbe Analysis of physical transformation of residential buildings in selected government estates in south western Nigeria, Unpublished Ph.D Thesis, Department of Architecture, The Federal University of Technology, Akure, Nigeria, 2011

[7] J. S. Ajanlekoko Sustainable housing development in Nigeria - the financial and infrastructural implication, Proceedings of the International Conference on Spatial Information for Sustainable Development, Nairobi, Kenya, 2 - 5 October, 2001

[8] Federal Office of Statistics Nigeria Poverty Profile for Nigeria: An Analysis of the 2004 National Consumer Survey Abuja: Federal Office of Statistics Abuja, Nigeria, 2006

[9] Federal Government of Nigeria Official Gazette: legal notice on publication of census 2006 report, Federal Government Printer, Lagos, Nigeria, 2007

[10] A. O. Olotuah Towards meeting low-income earners housing needs in Ado-Ekiti, Nigeria" Journal of the Nigerian Institute of Town Planners, Oct; XV, pp. 15-24, 2002

[11] A. O. Olotuah The state of repair of buildings in Akure, Nigeria" Proceedings of CIB W107 Construction in Developing Economies International Symposium, "Construction in Developing Economies: New Issues and Challenges", 18-20 January, Santiago, Chile, Paper 3.1 CD ROM, 2006

[12] J. Wahab, L. A. Adedokun, A. G. Onibokun Urban housing conditions, In Onibokun A. G. (Ed.) Urban Housing in Nigeria, Nigerian Institute of Social and Economic Research (NISER), Ibadan, pp. 89 - 140, 1990

[13] U. O. Nkwogu Sustainable urban development policy issues in Nigeria, In U. O. Nkwogu (Ed.) Architects and architecture in Nigeria: a tribute to Prof. E. A. Adeyemi, Association of Architectural Educators in Nigeria, pp. 177 - 208, 2001

[14] L. M. Olanitori and A. O. Olotuah The effect of clayey impurities in sand on the crushing strength of concrete- a case study of sand in Akure metropolis, Ondo State Nigeria, Proceedings of Our World in Concrete and Structures Conference, Singapore, Conference Documentation Vol. XXIV pp. 373- 376, 2005

[15] G. Fadairo and A. O. Olotuah Low-cost housing for the urban poor in Akure, Nigeria: materials and techniques of construction. Journal of Environment and Earth Science www.iiste.org ISSN 142-2224-3216 (Paper) ISSN 2225-0948 (Online) 3 (9) 135, 2013 http://iiste.org/Journals/index.php/JEES/article/download/7335/7582

[16] A. O. Olotuah Housing delivery and financial intermediation: an appraisal of the roles and performances of mortgage institutions in Nigeria The Quantity Surveyor, 35, pp. 20-27, 2001

[17] J. Dethier Down to Earth - Mud Architecture, an Old Idea, A New Future: Paris, 1982

[18] M. Calkin Materials for Sustainable Sites: A Guide to the Evaluation, Selection and Use of Use Sustainable Construction Materials, Hoboken, NJ, USA: John Willey \& Sons, 2009

[19] B. Sodagar, R. Fieldson and B. Gilroy-Scott Design for sustainable architecture and environments: The International Journal of Environmental, Cultural, Economic and Social Sustainability, 4 (4) 73 $-84,2008$

[20] B. Sodagar, D. R. Rai, J. Murphy. and H. Altan The role of ecorefurbishment in Sustainable construction and built environment, in Proceedings of the 3rd CIB International Conference on Smart and Sustainable Built Environments (SASBE), Delft, the Netherlands, pp. 15-19 June, 2009

[21] M. Asif, T. Muneer. and R. Kelly Life cycle assessment: A case study of a dwelling home In Scotland, Building and Environment, 42, 1391, 2007 https://doi.org/10.1016/j.buildenv.2005.11.023

[22] A. O. Olotuah. and A. A. Taiwo Housing the urban poor in Nigeria through low-Cost housing Schemes. International Journal of Physical and Human Geography, (European Centre for Research, Training and Development, U.K.) 1 (3), pp. $1-8,2013$
[23] J. O. Afolayan. and A. Ocholi Isosafety parameters for fink - type steel roof trusses. Structural Engineering, Mechanics and Computation, Vol 2, Zingoni A. (Ed.), Elsevier Science, April, pp. 1129 - 1136, 2001

[24] B. Sodagar, D. Rai, B. Jones, J. Wihan. and R. Fieldson The carbon reduction potential of strawbale housing. Building Research \& Information, 39 (1) pp. 51 - 65, 2011 https://doi.org/10.1080/09613218.2010.528187

[25] I. C. Ezema, O. I. Fagbenle, and A. O. Olotuah Estimating embodied energy in residential buildings in a Nigerian context. International Journal of Applied Engineering Research, 10, (24) 44140 - 44149, 2015 EID: 2-s2.084955569618http://www.scopus.com/inward/record.url?eid=2-s2.084955569618\&partnerID=MN8TOARS

[26] M. K. Dixit, J. L. Fernandez-Solis, S. Lavy and C. H. Culp Need for an embodied energy measurement protocol for buildings: A review paper, Renewable and Sustainable Energy Reviews, 16, pp. 3730-3743, 2012 https://doi.org/10.1016/j.rser.2012.03.021

[27] Z Alwan and P. Jones The importance of embodied energy in carbon footprint assessment, Structural Survey, 32 (1) pp. 49-60, 2014 https://doi.org/10.1108/SS-01-2013-0012

[28] W. F. Schwerdtfeger Traditional Homing in African Cities - A Comparative Study of Houses in Zaria, Ibadan and Marrakech; John Wliley \& Sons. Ltd; Chicester, 1982

[29] D. C. I. Okpala Promoting the use of local building materials in nigerian housing construction: the problems and the prospects, In Onibokun, A. G. (Ed.) Housing in Nigeria, Nigerian Institute of Social and Economic Research (N.I.S.E.R) Ibadan, Nigeria, 1985

[30] M. A. Olade Technology and developing nations - the way out (strategies for industrial development in Nigeria) Text of 1987 Foundation Lecture, Ondo State Polytechnic, Owo, Nigeria, 1987

[31] O. J. Shittu and J. Aderiye Exploitation of Clay As a Building Material In Ekiti State (An Overview), The Journal of Techno-Science, 2 (1) pp. $13-19,1998$

[32] F. A. Akintola Geology and geomorphology, In Babour R.M. (Ed.) Nigeria in Maps, Hodder and Stoughton, London, 1982

[33] A. O. Madedor Local building materials - source and utilization. In Rural Housing Development in Nigeria; Proceedings of the National Seminar Held at Aguru Hotel, Abuja, Oct. 14 - 15, pp. 52 - 62, 1987

[34] E. O. Olabiran, E. O. Asaolu, and C. R. Etuta Innovative local materials for use in housing, Proceedings of the National Workshop of the Association of Housing Corporations of Nigeria, Kano, Nigeria, pp. 149 $-165,1989$

[35] A. O. Ojo and A. O. Oyinloye Physical and mineralogical evaluation of clay deposits at Ado-Ekiti and Ikere-Ekiti, Ekiti State, Nigeria. The Journal of Techno-Science, 2 (1) pp. 49 - 52, 1998

[36] H. J. Osinubi Effect of lime content and curing period on permeability of stabilized lateritic soil, The Journal of Techno-science, 2 (1) pp. 60 67, 1998

[37] A. O. Madedor Local building materials - source and utilization. In Rural Housing Development in Nigeria; Proceedings of the National Seminar Held at Aguru Hotel, Abuja, Oct. 14 - 15, pp. 52 - 62, 1987

[38] E. O. Olabiran, E. O. Asaolu, and C. R. Etuta Innovative local materials for use in housing, Proceedings of the National Workshop of the Association of Housing Corporations of Nigeria, Kano, Nigeria, pp. 149 $-165,1989$

[39] R. B. Lawal Enhancing indigenous building materials performance and construction systems for low-cost housing, Nigerian Building and Road Research Institute (NBRRI) Occasional Publication, 2005

[40] C. Arum Effect of packing densities of aggregates on the workability and compressive strength of concretes. Paper accepted for presentation at West Africa Built Environment Research (WABER) Conference, Abuja July, 2012

[41] C. Arum, C. M. Ikumapayi and G. O. Aralepo Ashes of Biogenic Wastes - Pozzolanicity, Prospects for Use, and Effects on Some Engineering Properties of Concrete. Materials Sciences and Applications, 4, pp. 521-527, 2013 http://dx.doi.org/10.4236/msa.2013.49064 